\title{
Pandemic politics in South Asia: Muslims and democracy
}

Edition 4, 2020

Associate Professor Matthew J. Nelson

DOI: 10.37839/MAR2652-550X4.4

References to regime type figure prominently in analyses of the global COVID-19 pandemic and state responses to it: an 'authoritarian' transparency deficit in China allowed the pandemic to spread before disciplined bureaucratic intervention tackled it; 'democratic' openness left the United States vulnerable even as traditions of personal liberty and grassroots authority stifled a coordinated response. Within these analytical caricatures, or ideal types, two different notions of state effectiveness emerge, each rooted in its own account of the link between state capacity and legitimacy. In the authoritarian caricature, high levels of bureaucratic capacity are said to boost policy legitimacy. In the democratic caricature, electoral legitimacy is expected to enhance the state's administrative capacity and effectiveness.

In democratic states, however, patterns of legitimacy are often mediated by entrenched social divisions, with electoral legitimacy varying across social groups. Patterned social exclusion thus creates segmented patterns of legitimacy and, then, uneven patterns of state capacity and effectiveness. In such contexts, efforts to avoid nuanced engagement with existing social cleavages by invoking blanket 'emergency' powers (limiting fundamental rights) often push marginalised groups away from compliance towards resistance. In the Chinese model, appeals to emergency powers might actually enhance bureaucratic capacity and, thus, legitimacy. But, almost by definition, policy effectiveness in democracies is said to follow from modes of legitimacy that avoid emergency powers: in democracies, ordinary laws appealing to an inclusive political centre are expected to enhance both the legitimacy and the 
effectiveness of the state.

In South Asia, segmented social cleavages are closely tied to religion. And, in this context, I examine elected regimes grappling with social divisions focused on Islam or Muslims. Specifically, I examine four cases in which segmented state approaches to the COVID-19 pandemic have overlapped with a sense of marginalisation amongst Muslims (or particular groups of Muslims), namely India, Kashmir, Pakistan, and Afghanistan. In all four cases failures of popular buy-in focused on Muslims have shaped both rhetorical and policy responses to the pandemic. These failures, I argue, have weakened state capacity as well as democracy in the region.

\section{Indian Muslims: Increased marginalisation}

Around the world, responses to the COVID-19 pandemic routinely discriminate against weaker communities. In 2006, a report by India's Sachar Committee clarified that, even more than Dalits (formerly 'untouchables'), Muslims are India's weakest community. This marginalisation has figured prominently in India's pandemic response.

Within India, the first cases of COVID-19 were detected in late-January 2020 among students returning to Kerala (South India) from Wuhan (China). After an infected Sikh prayer leader attended several religious events 8-10 March, his death on 18 March led to quarantine measures for several Punjabi villages. But, starting in lateMarch, the 'Hindutva' (Hindu nationalist) orientation of India's current government under Prime Minister Narendra Modi-himself a long-time member of the Rashtriya Swayamsevak Sangh or RSS (a civil-society organisation committed to notions of 'racial purity' modelled on early-twentieth-century European fascism)-targeted India's Muslims both rhetorically and legally for blame. Specifically, a Deobandi Sunni Muslim movement known as the Tablighi Jama'at, known for its focus on intraMuslim proselytisation calling Muslims 'back' to Deobandi mosques around the world, attracted attention as infections within the group spread from a late-February 
meeting in Kuala Lumpur (Malaysia) across Southeast Asia to India.[1]

On 11 March, India's Cabinet Secretary urged India's states to invoke a colonial emergency law known as the Epidemic Diseases Act (1897) allowing mandatory quarantine on suspicion of infection whilst ensuring that any official acting 'in good faith' would not be prosecuted. And, on 13 March, even as India's parliament continued to meet in New Delhi, state-level officials in India's National Capital Region prohibited events with more than 200 attendees (later reduced to 50). Still, the Tablighi Jama'at launched a three-day event on 13 March with thousands of attendees who had been gathering in anticipation of this annual event for at least the previous two weeks at its Nizamuddin (South Delhi) headquarters. More than 1,500 Tablighi Jama'at members left New Delhi after 15 March. But, on 17 March, an Indonesian attendee tested positive in Hyderabad (1,500km south of Delhi). And, four days later, as the Hyderabad cluster grew to ten, India's government launched a nationwide contact-tracing effort focused on the Tablighi Jama'at. Delhi was locked down on 23 March. And, the following day, with just four hours' notice, Prime Minister Modi extended this lockdown nationwide.

The selective targeting of India's Muslims, however, was brought into sharp relief only 24 hours later, when the Chief Minister of a North Indian state known as Uttar Pradesh-himself also a leading member of the RSS-violated Modi's lockdown by participating in a group ceremony advancing the construction of a controversial Hindu temple in Ayodhya. The Chief Minister was not reprimanded. But, within a week, the leader of the Tablighi Jama'at headquarters in Nizamuddin was charged under the Epidemic Diseases Act (1897) for violating Delhi's social-distancing rules; scarcely two weeks after that, his charges were elevated to 'culpable homicide'.

At the same time, breaking the anti-stigmatisation rules established by Modi's own govern-ment, official daily COVID-19 briefings began to highlight higher rates of infection amongst Tablighi Jama'at affiliates (failing to mention higher rates of testing for this targeted cohort). And, on April 4, the president of Prime Minister Modi's ruling Bharatiya Janata Party (BJP) in the North Indian state of Himachal 
Pradesh compared affiliates of the Tablighi Jama'at to 'human bombs'. His statement was repeated by the BJP's former Chief Minister in Maharashtra. But this pattern of demonisation-indeed overt securitisation-was not limited to BJP statements targeting the Tablighi Jama'at. Building on Twitter handles like \#coronajihad (read by more than 165 million people), one state-level BJP politician played on more general Islamophobic tropes, referring to 'coronaterrorism'. Modi's only Muslim minister-a Shi'i Muslim serving as India's Minister for Minority Affairs-tapped into specific intra-Muslim divisions by describing the pandemic as a (Sunni/Deobandi) 'Talibani' crime.

This was not a blanket emergency response treating all Indians as equal citizens. Instead it was a segmented response focused on the marginalisation, stigmatisation, and securitisation of Muslims-one that departed from any constitutional commitment to equal citizenship (Article 15) or, for that matter, any democratic political appeal to widespread popular buy-in. In India, the ruling party's response to the pandemic built on existing social cleavages in ways that reinforced a 'segmented' approach to state legitimacy. In fact India's selective application of existing laws challenged the formal underpinnings of a modern liberal democracy.

\section{Kashmiri Muslims: Further securitisation}

For decades, so-called 'Indian-administered Kashmir' was India's only Muslimmajority state. Patterns of Muslim marginalisation and securitisation had been a matter of routine in that state long before the arrival of COVID-19. But, in 2020, the pandemic provided a new emergency 'envelope' for longstanding forms of securitisation as well as ongoing forms of political and demographic transformation. Specifically, sweeping curfews put in place to stifle Muslim protests targeting controversial constitutional changes introduced by Prime Minister Modi's BJP government in August 2019 were replaced, just a few days after being lifted in March 2020, with COVID-19 'lockdowns'. And, then, during these lockdowns, further measures designed to dilute or displace Kashmir's Muslim majority were also 
introduced.

The political background surrounding these developments is complex. In June 2018, citing a failure to tackle local security problems, the BJP withdrew from the ruling state-level coalition in Kashmir, bringing down the region's government and prompting a six-month stretch of 'Governor's Rule' (followed, in January 2019, by 'President's Rule' placing Kashmir directly under the rule of India's parliament). After the BJP secured an absolute majority in India's parliamentary elections five months later, however, Prime Minister Modi renewed his government's imposition of President's Rule. And, then, heeding the BJP's election manifesto, he moved to 'abrogate' Kashmir's special constitutional status.

This abrogation in August 2019 unfolded in four steps. First, the government in New Delhi amended a constitutional provision known as Article 367 to ensure that, henceforth, any constitutional reference to Kashmir's 'Constituent' Assembly would refer to Kashmir's state-level 'Legislative' Assembly, i.e. Kashmir's state-level government. (According to Article 367, any reference to a state-level government in India also includes forms of Governor's or President's Rule.) Second, as per Article 370, India's President was asked to 'consult' and 'concur' with Kashmir's state-level government-no longer its 'Constituent' or 'Legislative' Assembly but, owing to President's Rule, the Indian parliament-to abrogate, or remove, any hint of Kashmir's historically embedded constitutional autonomy. Third, having nullified the forms of autonomy previously articulated in Article 370, India's parliament redefined Jammu and Kashmir, as well as Ladakh, as two new 'union' territories governed directly by India's parliament (with limited powers for a new Legislative Assembly in the union territory of Jammu and Kashmir). Finally, India's parliament revised rules limiting property ownership to ancestral Kashmiri 'residents,' opening up residency, property, and public employment opportunities to many other Indians. In short, India's parliament under the BJP laid the constitutional and legal groundwork for (a) erasing the autonomous 'state' of Kashmir as well as (b) profound demographic changes erasing Kashmir's Muslim majority. 
To stifle expected protests, almost all of Kashmir's non-BJP politicians were arrested. Public meetings of more than four were prohibited under Section 144 of India's Criminal Procedure Code (targeting 'public disorder' with restrictions lasting up to eight months). A communications blockade silencing phones and severely limiting internet access-the longest internet blockade in any modern democracy-was also imposed. In short, Kashmir was placed under a type of siege for nearly six months until a Supreme Court review led most restrictions to be lifted, including, finally, in mid-March, internet restrictions (still limited to 2G). The simultaneous escalation of the government's anti-COVID-19 efforts in mid-March, however, allowed for a reimposition of numerous restrictions almost immediately, including the use of farreaching discretionary powers as per India's Unlawful Activities (Prevention) Act (1967) (ULPA) as well as its draconian Jammu and Kashmir Public Safety Act (1978) (PSA). The ULPA provides only vague definitions of political speech that might be seen as articulating 'disaffection against India', allowing six months of detention without any presentation of charges. The PSA rests on broad claims regarding 'public order' whilst restricting legal representation for people thrown into preventive detention. Recalling the Epidemic Diseases Act (1897), the PSA also shields officials acting 'in good faith' from any legal accountability. Indeed, just as India was facing its first COVID-19 lockdown after 24 March, the government announced new residency laws intended to reduce Kashmir's Muslim majority.

It would be difficult to describe a more dramatic escalation of Muslim marginalisation under the cover of COVID-19. What distinguished the experience of Kashmir, however, was not merely the segmented marginalisation and securitisation of Muslims, but the use of legal provisions that explicitly 'suspended' democratic norms in order to deal with an emergency-provisions that might have been expected to expire, were it not for COVID-19, which simply placed old 'public-order' restrictions into a new 'public-health' legal envelope.

In the first six months of the pandemic, Kashmir had seen relatively few infections partially owing to its rigid lockdown. But, whereas Kerala's state-level government kept early infection rates fairly low following a 'democratic' model focused on the 
cultivation of cross-cleavage policy legitimacy via universal testing and contacttracing, shelters for migrants, and free meals alongside improved internet access (to facilitate lockdown compliance), Kashmir reinforced segmented patterns of legitimacy. Indeed, whereas Kerala adopted a 'democratic' approach to public health, the Indian government in Kashmir adopted an 'emergency' model focused on a suspension of democratic norms.

\section{Pakistani Muslims: Resisting regulation}

Whereas U.S. President Donald Trump seized on early transmission patterns to demonise what he called the 'Chinese' virus and BJP politicians in India focused on early transmission patterns to demonise a so-called 'Muslim' or (Sunni/Deobandi) 'Talibani' virus, Sunni Deobandi figures in Pakistan focused on early infections amongst Shi'i pilgrims returning from Iran to warn of a menacing 'Shi'i' virus. This pattern of intra-Muslim demonisation, however, was not limited to non-state actors. In Pakistan, returning Shi'i pilgrims also faced deplorable conditions in official quarantine facilities. And, in the province of Balochistan, officials used the virus as a pretext to extend their harassment of a beleaguered Shi'i minority known as the Hazara. Evidently, Muslim-majority Pakistan was not immune to pandemic-based patterns of stigmatisation targeting 'Muslim minorities'.

Within Pakistan, however, the most important trends did not focus on the marginalisation of Muslim minorities; instead, government efforts to contain the pandemic energised Muslim opposition groups seeking to preserve their sense of religious and institutional autonomy. In fact, as in Kashmir, concerns about social and political marginalisation were tied to forms of resistance targeting state-led patterns of administrative 'assimilation'. Again, the state's engagement with existing social divisions overlapped with uneven patterns of state legitimacy. These segmented patterns of legitimacy, in turn, restricted the state's overall administrative capacity. 
Repeating a familiar line amongst religious leaders who claim that God, notgovernment, is their primary source of protection, prominent clerics from Pakistan's Sunni Deobandi and Sunni Barelwi sub-denominations insisted that faith alone was a powerful prophylactic against the virus. They argued that government intervention was not merely unnecessary but objectionable, with government anti-virus measures being framed as a conspiracy led by anti-Muslim foreign governments to undermine the power of Islam. Like clerics battling scientists to sight the moon at the end of Ramadan, the pandemic was recast as another platform for religious elites to compete with state-sanctioned secular elites in a push to define the parameters of popular legitimacy.

Government policies seeking to prevent mosques from allowing collective prayers in close proximity emerged as a particular bone of contention, with police battling worshippers at several mosques. But, having said this, clerics in various parts of the Middle East-from Saudi Arabia and the United Arab Emirates to Egypt and Turkey (notwithstanding their very different religious politics)-heeded state-sanctioned fatwas allowing ritual adaptations designed to thwart the pandemic. Indeed, religious leaders in Pakistan seemed to use the pandemic to demonstrate their commitment to institutional autonomy.

One voice of resistance, however, was particularly concerning, namely that of Maulana Abdul Aziz. In 2007, Aziz helped to lead a stand-off with the government at Islamabad's Lal Masjid (Red Mosque) that culminated in a military assault killing more than 100 and prompting the formation of the Tehreek-e-Taliban Pakistan (TTP). The TTP went on to perpetrate seven years of terrorist attacks across Pakistan, ostensibly in revenge. As such, few were surprised when the government opted for a negotiated settlement with those opposed to mosque closures, agreeing one week before the start of Ramadan-a month of increased mosque donations-that, faced with COVID-19, mosques should remain open as an essential community service (so long as ablutions were completed at home, worshippers carried their own prayer mats, and social distancing rules were observed). Still, enforcement was lax, and throughout Ramadan infections increased, leading to further appeals for additional 
precautions before the holiday of Eid-ul-Adha in July.

Already in late-March, the state had sought to bypass Pakistan's deeply divided social and political landscape with the introduction of blanket 'emergency' provisions that directly diluted democracy. Specifically, the Pakistan Army pressed the government to activate a constitutional provision known as Article 245 allowing the military to intervene 'in aid of civilian authority'. Limiting the jurisdiction of provincial High Courts, this measure allowed the military to act, not only with respect to COVID-19, but in any 'area' (that is, any territory, including sensitive territories like Balochistan) with impunity. And so, again, even beyond clerical concerns regarding a segmented pandemic response targeting particular groups of Muslims (e.g. mosque leaders), Pakistan's tilt towards an anti-democratic response is clear.

As in India, and again in Kashmir, Pakistan's approach to the pandemic combined already-existing forms of social marginalisation with enduring patterns of religious resistance to state-based assimilation or 'encroachment'. And, as in Kashmir, Pakistan opted to reject democratic norms-including fundamental rights-in favour of emergency provisions.

\section{Afghan Muslims: Complicating negotiations}

In Afghanistan, existing social cleavages unfold on multiple levels. With reference to COVID-19, however, cleavages separating (a) the elected Afghan government-itself divided between President Ashraf Ghani and his rival Abdullah Abdullah-from (b) Afghan Taliban insurgents (ethnically Pashtun and doctrinally Sunni/Deobandi but divided by rivalries between local commanders) have been especially important. Above all, government and Taliban efforts to tackle the pandemic-sometimes cooperating, sometimes competing-have failed to coalesce owing to competitive posturing on both sides before a first round of peace talks (beginning in September), with government and Taliban efforts to delegitimise one another significantly 
reducing public-health capacity.

For years, the Taliban sought to present themselves as an alternative to the Afghan government by providing public services (e.g. speedy justice). But, at the same time, they attacked government employees, including teachers and health workers, to weaken the government's capacity and, thus, its legitimacy. Without many qualified health experts of their own, however, the Taliban often sought to control or manage government and NGO-contracted health services in the districts they captured. And, in a similar vein, they seized bilateral COVID-19 food aid and distributed it themselves. Other forms of pandemic-related assistance were caught up in familiar webs of governmental patronage and corruption, often reinforcing Taliban efforts to delegitimise the state.

Whereas rival militant groups like Daesh or Islamic State followed clerics like Maulana Abdul Aziz in Pakistan, describing the pandemic as a form of 'divine punishment', however, the Taliban opted for a different approach, beginning with an effort to quarantine (not kill) Shi'i pilgrims returning from Iran. (As in Pakistan, Afghanistan's first COVID-19 cases in late February emerged in the western city of Herat amongst Afghan refugees fleeing Iran's early outbreak as well as Shi'i pilgrims returning from the central Iranian city of Qom.) In fact, having relaxed a 2019 ban on the World Health Organisation (WHO) and the International Committee of the Red Cross (ICRC) to resist anti-polio vaccination efforts-recall that Osama bin Laden was located by a CIA agent masquerading as a vaccination canvasser-the Taliban also noted that they would provide safe passage for selected medics in the areas they controlled. Indeed, Taliban commanders in some districts also cooperated with international organisations-even, in some cases, Afghan officials-to ensure that Afghans infected with COVID-19 could be transported to government hospitals for treatment. And, by late-March, they launched a health awareness campaign, both online and in person, to stress the value of hand hygiene, face masks, and social distancing.

On April 2, the Taliban went on to announce (partly as a matter of self-preservation) 
that they would not fight in areas with detected coronavirus cases. And, just three days later, an Ulema High Commission established by the government to stifle the pandemic issued a fatwa to shutter Afghan mosques; in fact, as Ramadan unfolded, Taliban spokesman Zabiullah Mujahid urged Taliban clerics to consider a late-March fatwa issued by Afghanistan's National Ulema Council asking Sunni Muslims to pray at home. (Afghan Shi'a followed similar orders issued by clerics in Iran.) Throughout, however, the focus of the Taliban was on information more than enforcement. After a three-day Eid-ul-Fitr ceasefire marking the end of Ramadan, fighting resumed and the rate of infections soared.

Anticipating intra-Afghan talks in which the Taliban hoped to build on their military position with a bid for enhanced political power, the Taliban's goals, with respect to COVID-19, were always mostly rhetorical. These goals lay in presenting the Taliban as a force that could be relied on to interface with international and domestic partners in areas of common concern, e.g. a global pandemic. Indeed, beyond any intrinsic commitment to policy coordination, unpacking the Taliban's anticoronavirus 'cooperation' with international and government agencies cannot be understood apart from the Taliban's anti-government 'competition' in advance of possible peace talks: briefly, the Taliban seized on COVID-19 'to present itself as an entity capable of governing more effectively than the elected ... government', argued Bill Roggio from the Foundation for the Defense of Democracies. Specifically, returning to existing social and political cleavages, Roggio noted that '[t]he Taliban ... use[d] COVID-19 as a wedge issue to delegitimise the [elected] Afghan government and further promote its [undemocratic] Islamic Emirate'.

In short, a global COVID-19 pandemic was not enough to bridge the most important social and political cleavages in Afghanistan. On the contrary, the pandemic reinforced those cleavages and bolstered the Taliban's delegitimisation of Afghanistan's elected government. 


\section{Conclusion}

In South Asia, legitimacy gaps associated with entrenched social and political cleavages involving Muslims or particular groups of Muslims have shaped state efforts to address the global COVID-19 pandemic: one virus, different contexts, each with specific patterns exacerbated by the virus. If there is one pattern that has prevailed across all four cases (India, Kashmir, Pakistan, and Afghanistan), however, it is a pattern pushing away from the legitimacy of elected governments and away from democratic norms.

COVID-19 has not initiated any 'new' trends in Muslim South Asia. It has simply exacerbated and perhaps accelerated key trends already shaping the region. In this sense, the pandemic has altered the political landscape much as climate change has altered our weather, introducing more intense versions of already-familiar challenges: stronger hurricanes (of Hindu majoritarianism in India); longer droughts (limiting civil liberties in Kashmir); more expansive floods (of anti-state protest in Pakistan); hotter fires (of religious authoritarianism in Afghanistan). In fact, like climate change, what began as a simple quantitative shift-more events of greater intensity-has slowly shifted in the direction of a qualitative change eroding the coastline of democracy.

There is a risk that COVID-19 analysts will focus on state capacity more than state legitimacy (or segmented legitimacy), inadvertently supporting either (a) a Chinese model of bureaucratic state capacity (e.g. biosurveillance) or (b) an anti-democratic model focused on emergency powers-not in the service of that old chestnut, 'public order', but rather in the service of a new emergency framed by 'public health'. This shift may help elected leaders defeat the virus. But, as with so many emergencies, those leaders may succeed in defeating the virus only to discover that they have killed their democracies in the process.

[1] Deoband is a North Indian town hosting a Sunni madrasa famous for its push to (a) revive Muslim social power after the late-nineteenth-century colonial destruction 
of the Mughal Empire and (b) reform South Asian Muslim practices centred on Sufi shrines. The Tablighi Jama'at (TJ) is a Sunni 'Deobandi' movement.

Image: Indian police during the COVID-19 pandemic. Credit: Manoej Paateel/Shuttertockf 